\title{
STRATEGI PENINGKATAN KINERJA APARATUR PENGELOLA ASET DAERAH DI KABUPATEN TAPANULI TENGAH
}

\author{
The strategy for improving the performance of local official asset Manager \\ in Tapanuli Tengah Regency
}

\author{
Nalom Santun Sihombing 1, Dwi Rachmina², Ma'mun Sarma ${ }^{3}$ \\ ${ }^{1}$ Staff Dinas Pendapatan, Pengelola Keuangan Dan Aset Daerah. Kabupaten Tapanuli Tengah. Email. \\ nalomsih@gmail.com \\ 2 Staff Pengajar Departemen Agribisnis. Fakultas Ekonomi dan Manajemen Institut Pertanian Bogor. Email: \\ dwirachmina@gmail.com \\ 3 Staff Pengajar Departemen Ilmu Manajemen. Fakultas Ekonomi dan Manajemen Institut Pertanian Bogor. E- \\ mail: mamun_sarma@yahoo.com
}

\begin{abstract}
A qualified opinion (WDP) on LKPD Tapanuli Tengah Regency has become the focus of attention of the government in revamping asset management. The low performance of local official asset Manager caused problems in fixed assets, namely non-compliance with relevant regulations, operational procedures that are less clearly understood, and administrative error in asset management. The purpose of this sudy were to 1) Describe the system of supervision and controlling of local asset management; 2) Analyze internal and external factors in the asset management dan 3) Formulate strategy for improving the performance of the apparatus asset managers. The method used was the determining factor SWOT IFE and EFE, obtained in the form of a matrix IE grand strategy and prioritized through a matrix of pairwise comparison (pairwise comparisons matrix). This study used 74 respondents from 51 SKPDs composed of heads of office and local official asset managers. The results showed that the highest weight was found in internal factors. For external factors are the central government regulation of governance of regional assets, and governance support in accordance with the rules of government policy in favor of asset management. The highest strategic priority was to increase support government policies, both national and local human resource development to improve the competence of local asset managers through training to facilitate the administration of the assets in accordance with the rules of governance.
\end{abstract}

Key words: External Factor, Good Governance, Internal Factor, Priority strategy, Qualified Opinion,.

\section{ABSTRAK}

Opini wajar dengan pengecualian (WDP) atas LKPD Tapanuli Tengah menjadi fokus perhatian pemerintah dalam pembenahan pengelolaan aset. Rendahnya kinerja pengelola aset menyebabkan permasalahan pada aset tetap yaitu ketidakpatuhan terhadap peraturan terkait, prosedur operasional yang kurang jelas dipahami, kesalahan administratif dalam pengelolaan aset. Tujuan penelitian adalah 1) Mendeskripsikan sistem pengawasan dan pengendalian pengelolaan aset daerah, 2) Menganalisis faktor internal dan external pengelolaan aset, 3) Merumuskan strategi peningkatan kinerja aparatur pengelola aset daerah. Metode yang digunakan adalah SWOT (IFE dan EFE), diperoleh grand strategi berupa matriks IE, dan di prioritaskan melalui matriks perbandingan berpasangan (Pairwise comparisons matrix). Sampel penelitian ini terdiri dari 74 responden dari 51 SKPD terdiri dari pejabat dan pengelola aset. Berdasarkan hasil penelitian diperoleh bobot tertinggi pada faktor internal. Untuk faktor eksternal, peraturan pemerintah pusat tentang tata kelola aset daerah, untuk mempermudah tata kelola sesuai dengan aturan kebijakan pemerintah dalam mendukung Pengelolaan Aset. Prioritas strategi tertinggi adalah Meningkatkan dukungan kebijakan pemerintah, baik pusat dan daerah dalam pengembangan SDM dan peningkatan kompetensi pengelola aset daerah melalui pelatihan penatausahaan aset untuk mempermudah tata kelola sesuai dengan aturan.

Kata kunci: Faktor Eksternal, Good Governance, Strategi Intensif, Faktor Internal, Strategi Terintegrasi

\section{PENDAHULUAN}

Kinerja yang melandasi program birokrasi pemerintah ke depan adalah birokrasi yang profesional, bersih dan bebas dari korupsi, kolusi dan nepotisme serta tata kelola yang efektif dan efisien. Ketiga kata kunci tersebut dapat dijadikan landasan terwujudnya tata kelola pemerintahan yang 
baik dan bersih (good and clean governance). Prinsip/asas dari tata kelola pemerintahan yang baik merupakan petunjuk (guidance) bagi birokrasi pemerintah dalam menyelenggarakan tugas pokok dan fungsi pemerintahan negara dan pemerintahan daerah. Pengukuran kinerja menurut Tarr (1996) dilakukan dengan tujuan untuk mengawasi dan mengarahkan individu dan unit kerja (departments); umpan balik untuk menyesuaikan kinerja atau target; dan melakukan perbandingan antara kinerja dengan strategi dan tujuan dari "countinous improvement". Sementara itu pada organisasi sektor publik, pengukuran kinerja berdasarkan Peraturan Menteri PAN dan RB Nomor 29 Tahun 2010 dilakukan pada setiap akhir tahun anggaran yang ditetapkan dalam dokumen penetapan kinerja. Pengukuran pencapaian target kinerja tersebut dilakukan dengan membandingkan antara target kinerja dan realisasi kinerja dengan menggunakan formulir sebagaimana ditetapkan dalam peraturan tersebut. Dengan kata lain, pengukuran kinerja merupakan sebuah alat (instrumen) untuk menilai atau mengevaluasi kinerja para pimpinan (manager) di akhir periode pembukuan.

Opini wajar dengan pengecualian (WDP) atas LKPD Tapanuli Tengah untuk tahun 2009 sampai 2013 menjadi fokus perhatian pemerintah dalam pembenahan pengelolaan aset. Dalam opini tersebut di jelaskan adanya permasalahan pada aset tetap yaitu ketidakpatuhan terhadap peraturan terkait, prosedur operasional yang kurang jelas dipahami, kesalahan administratif dalam pengelolaan aset (human error). Sebagaimana diketahui bahwa dalam penyelenggaraan tugas dan fungsi pemerintahan negara dan pemerintahan daerah, ketersediaan sarana dan prasarana merupakan unsur mutlak yang harus ada sebagai wujud pelayanan kepada masyarakat. Sebagai unsur mutlak, maka sarana dan prasarana tersebut yang merupakan aset negara/daerah harus

${ }^{1}$ Zakiyudin, Ais. 2012. Masalah Terstruktur dan Tidak Terstruktur. Entri Populer diposkan pada 11 Mei 2012 di http://ais- dikelola secara efektif, efisien, transparan dan akuntabel sesuai dengan prinsip-prinsip good governance. Hal ini dikarenakan aset (kekayaan) negara/daerah merupakan bagian dari pengelolaan keuangan negara sebagaimana diatur dalam Undang Undang Nomor 17 Tahun 2003 tentang Keuangan Negara Pasal 2 yang menyebutkan bahwa keuangan negara meliputi kekayaan negara/kekayaan daerah yang dikelola sendiri atau oleh pihak lain berupa uang, surat berharga, piutang, barang, serta hak-hak lain yang dapat dinilai dengan uang, termasuk kekayaan yang dipisahkan pada perusahaan negara/ perusahaan daerah.

Perbaikan kondisi kinerja tersebut tentu tidaklah mudah karena kemungkinan organisasi menghadapi permasalahan yang terstruktur dan tidak terstruktur. Menurut Zakiyudin (2012), masalah terstruktur adalah masalah yang sering terjadi dan sifatnya berulang-ulang, sedangkan masalah tidak terstruktur adalah masalah yang jarang terjadi dan tidak berulang, serta tidak ada model untuk memecahkan masalah ini. ${ }^{1}$ Pada pemerintahan daerah, permasalahan dalam pengelolaan aset daerah diantaranya terjadi pada tahap penatausahaan aset daerah, tahap penilaian, tahap pengawasan dan pengendalian.

Untuk menghindari kesalahan yang sering terjadi di lapangan, seperti tidak menguasai penilaian aset, peran aparatur sangat dibutuhkan dalam menyesuaikan database dengan kondisi sebenarnya. Pengelola aset dalam melakukan penatausahaan perlu memahami terlebih dahulu tentang administrasi penatausahaan aset. Pemanfaatan barang milik daerah (BMD) harus diawasi dan dikendalikan secara tepat agar tidak terjadi salah urus (miss management), kehilangan, tidak termanfaatkan bahkan tidak teridentifikasi. Untuk meningkatkan fungsi pengawasan tersebut, peran aparatur dalam pengelolaan aset berpengaruh teradap laporan yang akan dihasilkan dari setiap instansi pengguna

zakiyudin.blogspot.co.id/2012/05/masalahterstruktur-dan-tidak.html diakses tanggal 13 Februari 2016 
aset. Proses penatausahaan dimulai dari awal sampai kepada pemanfaatan, selayaknya telah disusun dan tergambar dengan jelas, baik tahap demi tahap dari penilaian aset itu sendiri maupun jadwal waktu secara tepat.

Tujuan penelitian ini adalah untuk;

1. Mendeskripsikan sistem pengawasan dan pengendalian pengelolaan aset daerah di Kabupaten Tapanuli Tengah

2. Menganalisis faktor internal dan external pengelolaan aset di kabupaten tapanuli tengah

3. Merumuskan strategi peningkatan kinerja aparatur pengelola aset daerah di Kabupaten Tapanuli Tengah.

\section{METODE PENELITIAN}

\section{Lokasi dan Waktu Penelitian}

Penelitian ini dilakukan di Kabupaten Tapanuli Tengah, Provinsi Sumatera Utara. Pelaksanaan pengambilan data penelitian dilaksanakan selama tiga bulan pada bulan Februari sampai dengan April 2016.

\section{Jenis dan Sumber Data}

Penelitian ini menggunakan alat kuisioner yang disebarkan kepada pengelola aset. Pengambilan data primer ini dilakukan dengan penyebaran kuisioner dan in depth interview kepada pejabat pengguna barang. Pengambilan data Sekundar berupa pengambilan data Aset dan data yang mendukung penelitian ini.

\section{Metode Penentuan Sampel}

Populasi dalam penelitian ini adalah staf pengelola aset yang tersebar dari 51 SKPD. Sampel dalam penelitian ini ditentukan secara non probability sampling. Kriteria pemilihan sampel adalah pengelola aset yang hadir pada pengarahan persiapan pemeriksaan oleh BPK. Jumlah sampel dalam penelitian ini terdiri terdiri dari 74 aparatur yang terdiri dari Staf Pengelola aset yang berasal dari 51 SKPD. Penentuan prioritas strategi dilakukan kepada 7 orang ahli yaitu sekretaris daerah, kepala dinas DPPKAD, sekretaris DPPKAD, kabid aset dan 3 orang kepala seksi di bidang aset.

\section{Metode Analisis Data}

Metode analisis dalam penelitian ini adalah analisis deskriptif kualitatif. Langkah-langkah analisis yang dilakukan dalam penelitian ini sebagai berikut :

a. Menyimpulkan beberapa faktor yang menyusun faktor internal dan Eksternal.

b. Faktor internal dan eksternal tersebut dibobotkan melaui penyebaran kuisioner, untuk menghasilkan bobot tertinggi.

c. Dari indikator faktor internal dan eksternal tersebut, data nya diolah untuk memperoleh grand strategi.

d. Berdasarkan matriks SWOT (IFE dan EFE), diperoleh grand strategi berupa matriks IE.

e. Grand Strategy tersebut di breakdown untuk memperoleh beberapa alternatif strategi dengan metode SWOT.

f. Strategi yang diperoleh dari matriks swot, dibobotkan kembali untuk menentukan prioritas melalui kuisioner kepada pakar/ahli dengan menggunakan metode pairwise comparisons.

\section{HASIL DAN PEMBAHASAN}

\section{Kinerja Pengelolaan Aset di Kabupaten Tapanuli Tengah}

Laporan hasil pemeriksaan tahun anggaran 2013 di Kabupaten Tapanuli Tengah menunjukkan hasil WDP (Wajar dengan Pengecualian). Badan pemeriksa keuangan memberikan status WDP tersebut dengan kriteria antara lain: sistem pengendalian internal memadai, namun terdapat salah saji yang material pada beberapa pos laporan keuangan. Laporan keuangan dengan opini WDP dapat diandalkan, tetapi pemilik kepentingan harus memperhatikan beberapa permasalahan yang diungkapkan auditor atas pos yang dikecualikan tersebut agar tidak mengalami kekeliruan dalam pengambilan keputusan. Berdasarkan 
laporan hasil pemeriksaan (LHP) TA. 2013 di Kabupaten Tapanuli Tengah kondisi WDP tersebut disebabkan antara lain ; 1) Sekretaris daerah selaku pejabat pengelola barang milik daerah belum optimal dalam melakukan pengawasan dan pengendalian atas pengelolaan aset tetap di lingkungan pemerintahan Kabupaten Tapanuli Tengah, 2) Kepala DPPKAD dan kepala bidang aset belum optimal dalam melalukan pembinaan dan kordinasi dengan SKPD dalam pengelolaan dan penatausahaan aset serta dalam menyajikan data aset tetap pada laporan keuangan pemerintah Kabupaten Tapanuli Tengah, 3) Kepala SKPD di lingkungan Kabupaten Tapanuli Tengah selaku pengguna barang kurang memahami tanggungjawab dan ketentuan pengelolaan barang milik daerah, 4) Pengurus barang belum optimal dalam melakukan tupoksinya serta 5) ketersediaan anggaran terkait pengelolaan barang milik daerah belum optimal.

Beberapa upaya yang dilakukan oleh pemerintah Kabupaten Tapanuli Tengah untuk menindaklanjuti opini wajar dengan pengecualian (WDP) dilakukan antara lain ; 1) Melanjutkan validasi dan inventarisasi seluruh aset SKPD secara komprehensif, 2) Memantapkan sistem dan prosedur pengelolaan anggaran yang terkait dengan pengadaan aset, 3) Mensosialisasikan tata kelola keuangan yang baik pada seluruh jajaran pemerintahan sesuai dengan PP No. 58 Tahun 2005 dan Permendagri No 13 Tahun 2006 dengan pola bimbingan teknis serta diklat yang berkesinambungan, 4) Mengupayakan fasilitas e-audit yang terintregasi seperti Sistem Layanan Pengadaan Secara Elektronik (LPSE) dan 5) Mengembangkan secara terintegrasi, antara lain, sistem informasi management pembangunan daerah (SIMBANGDA), sistem informasi keuangan daerah (SIPKD), sistem informasi management hasil pengawasan (SIMHP), serta sistem pengelolaan barang milik daerah..

\section{Sistem Pengawasan dan Pengendalian Pengelolaan Aset Daerah}

$\begin{array}{ccr}\text { Sistem } & \text { pengawasan } & \text { dan } \\ \text { pengendalian } & \text { pengelolaan aset di }\end{array}$ Kabupaten Tapanuli Tengah dilaksanakan dalam beberapa kegiatan dimulai dari monitoring terhadap proses pengadaan, proses serah terima aset serta pencatatan dan pelaporan aset. Pada proses pengadaan aset, proses manajemen aset tahun berjalan dimulai dengan pengadaan barang yang dilakukan berdasarkan rencana pengadaan menurut belanja modal dalam DIPA tahun berjalan. Bukti pendukung terjadinya transaksi aset, disertai dengan dokumen lengkap yaitu, SPP, SPM, SP2D serta bukti pendukung aset tetap berupa dokumen tender, kontrak, progress report, berita acara pemeriksaan, berita acara serah terima barang bahkan kebenaran fisiknya.

Dalam penelitian yang dilakukan oleh Afandi dan Khairani (2013) atas manajemen aset tetap di Kota Tanjung Balai, mereka menemukan bahwa: "Pemanfaatan aset yang dikerjasamakan dengan pihak ketiga masih belum memberikan manfaat bagi pemda”. Dengan kata lain, pemanfaatan aset oleh pemerintah daerah masih belum memperhitungkan nilai tambah (value added) bagi kemakmuran masyakaratnya. Aset hanya dipandang sebagai sebuah aset semata, tanpa melihat potensi ekonomi yang terkandung di dalam aset tersebut.

Pengawasan dan pengendalian aset di Kabupaten Tapanuli Tengah juga dilaksanakan pada kegiatan serah terima aset yang dilaksanakan secara rutin kepada instansi. Hal ini dimaksudkan untuk keperluan database sebagai dasar pemantauan fisik aset baik luas tanah, bangunan, jumlah kendaraan dan inventaris termasuk nilainya sebagai bagian dari manajemen aset. Sesudah proses pengadaan barang selesai, segera aset diserahterimakan kepada rutin instansi untuk dicatat dan diakui sebagai aset yang berada di bawah penguasaan instansi tersebut. 
Sampai tahun 2015 belum semua instansi di Kabupaten Tapanuli Tengah mempunyai database yang memadai dan tidak dapat diandalkan (reliable). Beberapa hasil observasi lapangan yang menjadi kendala yaitu, terdapat aset yang belum diamankan baik secara fisik, administrasi dan hukum, serta beberapa barang dengan kondisi rusak berat atau hilang masih tercatat dalam buku inventaris dalam kondisi yang masih baik. Dalam kebijakan pencatatan aset tetap menyatakan bahwa, aset tetap yang tidak berfungsi atau dihentikan dari penggunaan aktif dan tidak memenuhi defenisi aset tetap dan harus dipindahkan ke pos aset lainnya sesuai dengan nilai tercatatnya

Prinsip dasar pengelolaan aset untuk dapat menjadi pedoman pengelola aset dalam penatausahaan antara lain adanya perencanaan yang tepat, pelaksanaan/pemanfaatan secara efesien dan efektif, dan pengawasan (monitoring).

Perubahan yang diperlukan dalam mengimplementasikan manajemen aset adalah terkait dengan pihak pengelola barang, pengguna barang dan pihak ketiga yang akan memanfaatkan/ memindahtangankan aset dengan cara memperkuat partisipasi publik (diwakili oleh masyarakat), private (diwakili pihak ketiga/swasta) dan komunitas (pengelola dan pengguna barang) dengan menciptakan accountability (akuntabilitas), transparency (transparan) dan rule of law (ketaatan peraturan) yang konsisten, openness (terbuka/fokus kepada stakeholder) sehingga stakeholder dapat menilai kinerja masing-masing pihak yang terlibat dalam manajemen aset, fairness (perlakuan yang adil) yang dapat meyakinkan berbagai pihak, terutama pihak swasta,bahwa tidak ada korupsi, kolusi dan nepotisme dalam pemanfaatan atau pemindahtanganan aset.

\section{Identifikasi Faktor Internal dan External Pengelolaan Aset di Kabupaten Tapanuli Tengah}

\section{Analisis Faktor Internal}

Berdasarkan pengolahan data kuesioner Faktor internal dan eksternal tersebut dibobotkan melaui penyebaran kuisioner, diperoleh hasil bahwa bobot tertinggi, indikator kebijakan pemerintah dalam mendukung pengelolaan aset merupakan indikator dengan bobot terbesar, indikator adanya hubungan baik antar SKPD pengelola aset merupakan indikator dengan bobot prioritas kedua mempengaruhi kinerja aparatur pengelola aset di Kabupaten Tapanuli Tengah, sedangkan bobot terkecil adalah belum optimalnya sumberdaya aparatur pengelola aset di Kabupaten Tapanuli Tengah dalam menerapkan standar operasional dan prosedur dalam mempengaruhi kinerja aparatur pengelola aset di Kabupaten Tapanuli Tengah.

Tabel 1. Evaluasi Faktor Internal (IFE)

\begin{tabular}{|c|c|c|c|c|}
\hline No. & Kekuatan & Bobot & Rating & $\begin{array}{c}\text { Skor } \\
\text { Terbobot }\end{array}$ \\
\hline 1 & $\begin{array}{l}\text { Kebijakan pemerintah Kabupaten Tapanuli Tengah dalam } \\
\text { mendukung Pengelolaan Aset }\end{array}$ & 0.1770 & 3.7973 & 0.6723 \\
\hline 2 & $\begin{array}{l}\text { Adanya Hubungan Baik Antar pengelola aset SKPD di Kabupaten } \\
\text { Tapanuli Tengah }\end{array}$ & 0.1720 & 3.7432 & 0.6439 \\
\hline 3 & $\begin{array}{l}\text { Manajemen dan Struktur Organisasi yang Jelas di Kabupaten } \\
\text { Tapanuli Tengah }\end{array}$ & 0.1273 & 3.7297 & 0.4749 \\
\hline 4 & $\begin{array}{l}\text { Sumberdaya Aparatur Pengelola Aset secara Kuntitas Memadai di } \\
\text { Kabupaten Tapanuli Tengah }\end{array}$ & 0.0954 & 3.5000 & 0.3338 \\
\hline 5 & $\begin{array}{l}\text { Pagu Anggaran yang memadai dalam Mendukung Peningkatan } \\
\text { KinerjaPegawai Pengelola Aset Daerah }\end{array}$ & 0.1216 & 3.3378 & 0.4060 \\
\hline 6 & $\begin{array}{l}\text { Adanya Komitmen yang kuat dari Seluruh Pengelola Aset di } \\
\text { Kabupaten Tapanuli Tengah dalam Mewujudkan Tujuan } \\
\text { Organisasi }\end{array}$ & 0.0807 & 3.2838 & 0.2649 \\
\hline
\end{tabular}




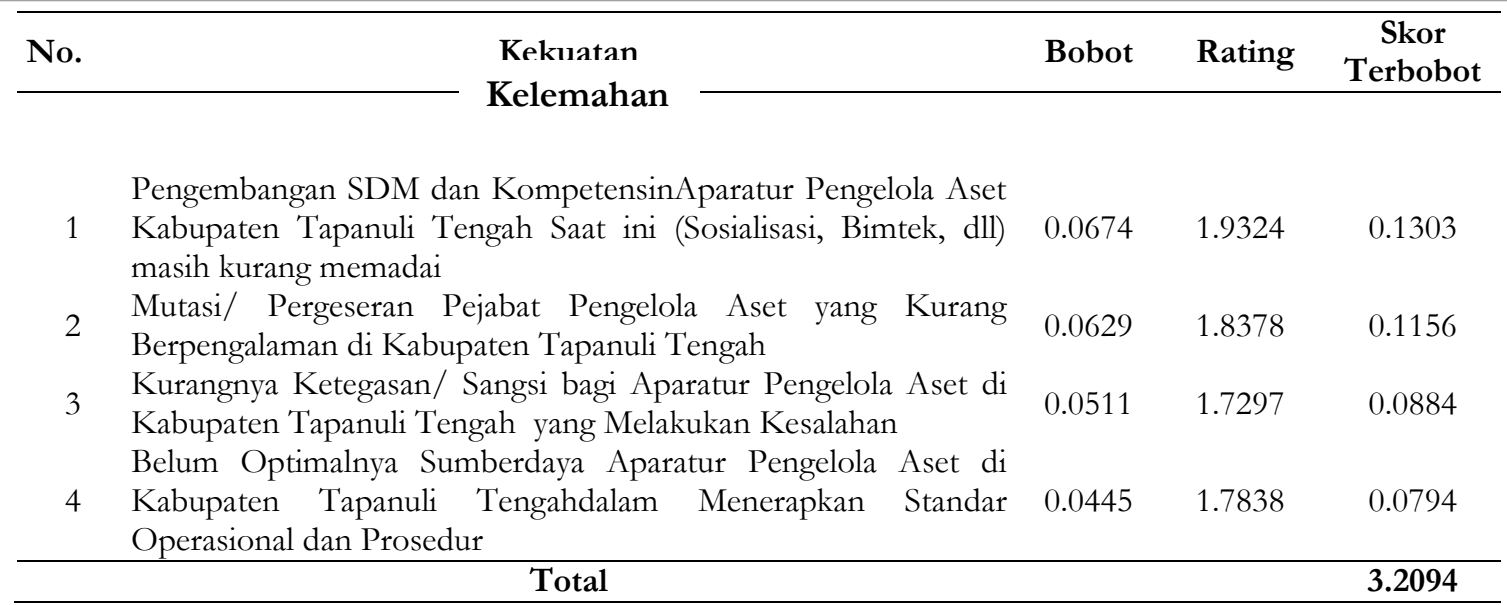

\section{Analisi Faktor Eksternal}

Pengolahan data evaluasi faktor eksternal, diperoleh hasil bahwa pada indikator peraturan tentang tata kelola aset daerah untuk mempermudah tata kelola sesuai aturan merupakan indikator dengan bobot tertinggi, diikuti dengan Indikator dana insentif daerah (DID) bagi pemerintah daerah yang berkinerja baik/opini WTP merupakan indikator terbesar selanjutnya.

Tabel 2. Evaluasi Faktor Eksternal (EFE)

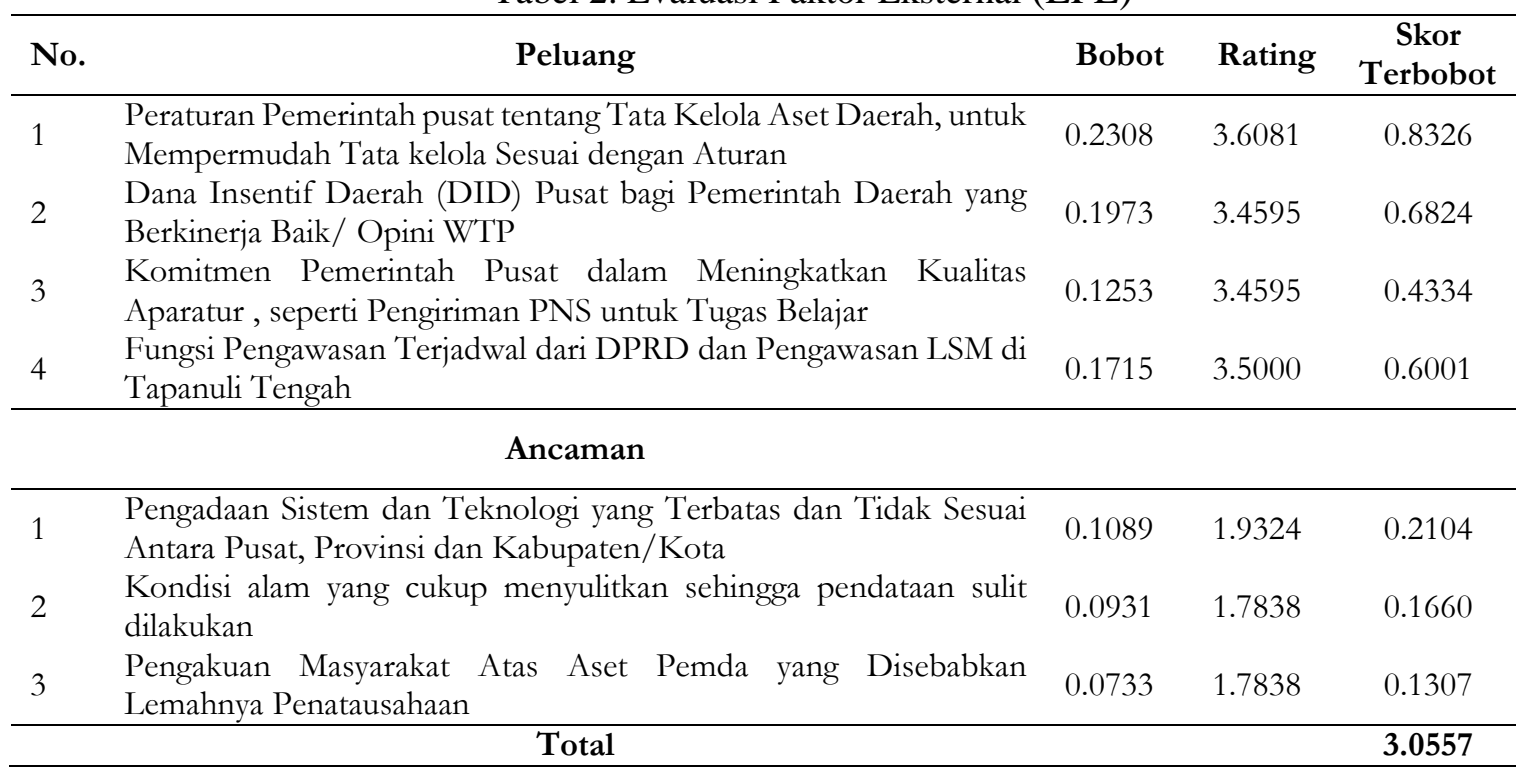

\section{Strategi Peningkatan Kinerja Aparatur Pengelola Aset Daerah}

\section{Analisis Internal-Eksternal}

Hasil Analisis Internal-Eksternal terhadap faktor yang mempengaruhi kinerja aparatur pengelola aset di Kabupaten
Tapanuli Tengah menunjukkan hasil berada pada sel I dengan strategi yang tepat adalah strategi tumbuh dan membangun (grow and build). strategi-strategi yang cocok adalah strategi intensif atau strategi terintegrasi (backward integration, forward integration dan horizontal integration). 


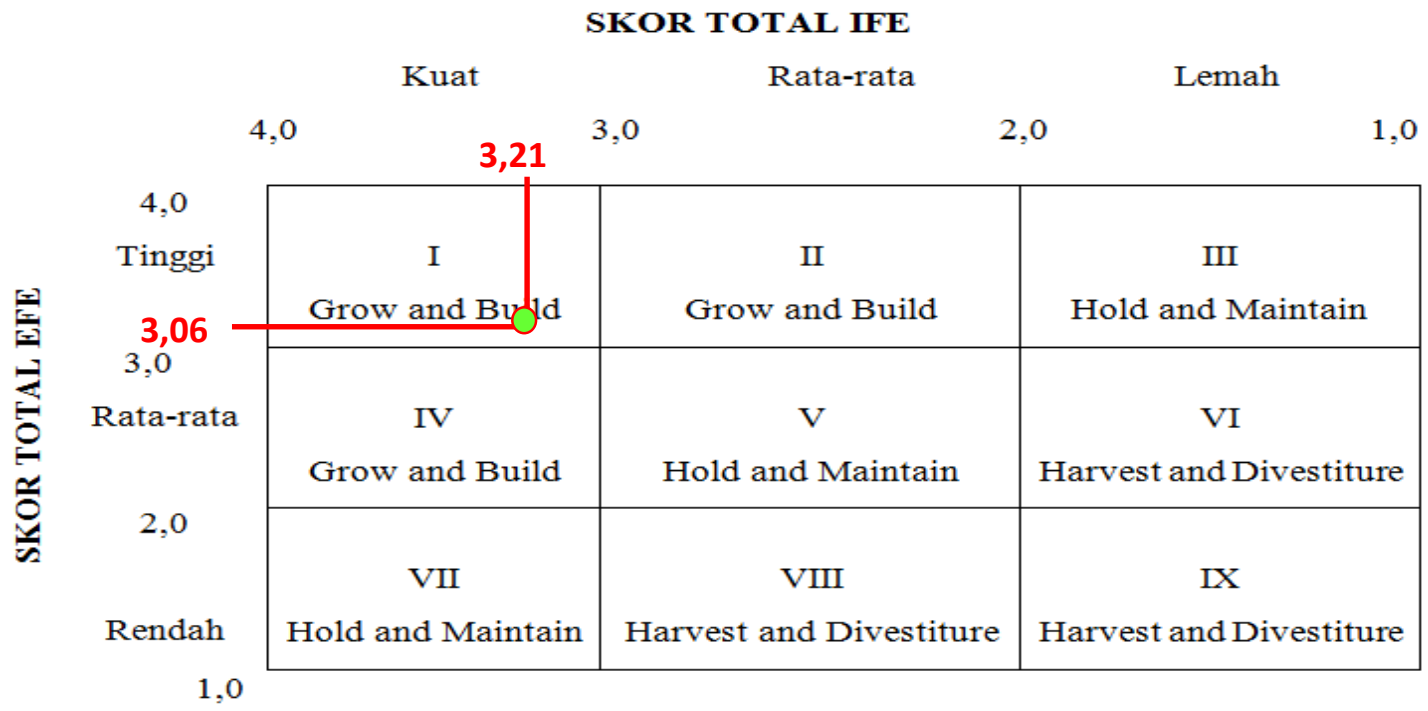

Gambar 1. Analisis IFE dan EFE

\section{Perumusan Alternatif Strategi}

Kekuatan, kelemahan, peluang dan ancaman yang ditemukan pada Kabupaten Tapanuli Tengah dimasukkan pada matrik SWOT. Tujuan matriks ini adalah untuk memaksimalkan kekuatan dan peluang dan secara bersama-sama meminimalkan kelemahan dan acaman. Dengan kata lain, matrik SWOT bertujuan untuk menggambarkan secara jelas bagaimana peluang dan ancaman eksternal dihadapi dengan memperhatikan kekuatan dan kelemahan yang dimiliki oleh pengelola aset Kabupaten Tapanuli Tengah.

Berdasarkan analisa SWOT dari faktor internal dan faktor eksternal terhadap faktor yang mempengaruhi kinerja aparatur pengelola aset di Kabupaten Tapanuli Tengah dengan berbagai indikator penyusunnya, maka diperoleh beberapa alternatif strategi yang mempengaruhi kinerja aparatur pengelola aset di Kabupaten Tapanuli Tengah dengan berbagai indikator penyusunnya, maka diperoleh beberapa alternatif strategi, antara lain:
1. Strategi S-O

Sinkronisasi peraturan pemerintah pusat, provinsi dengan kebijakan pemerintah Kabupaten Tapanuli Tengah dalam mendukung pengelolaan aset

2. Strategi $\mathrm{W}-\mathrm{O}$

Meningkatkan dukungan kebijakan pemerintah, baik pusat dan daerah dalam pengembangan SDM dan peningkatan kompetensi pengelola aset daerah melalui pelatihan penatausahaan aset untuk mempermudah tata kelola sesuai dengan aturan

3. Strategi S-T

Peningkatan kebijakan pemerintah dalam pengembangan dan penerapan sistem dan teknologi untuk mendukung pengawasan dan pengendalian dalam pengelolaan aset di Kabupaten Tapanuli Tengah. .

4. Strategi W-T

Peningkatan hubungan baik antar SKPD pengelola aset, terutama dalam penerapan sistem dan teknologi yang terintegrasi dalam pengelolaan aset di Kabupaten Tapanuli Tengah. 


\begin{tabular}{|c|c|c|}
\hline & Kekuatan (S) & Kelemahan (W) \\
\hline $\begin{array}{c}\text { STRATEGI PENINGKATAN } \\
\text { KINERJA APARATUR } \\
\text { PENGELOLA ASET DAERAH } \\
\text { UNTUK MENCAPAI TATA } \\
\text { KELOLA PEMERINTAHAN } \\
\text { YANG BAIK DI KABUPATEN } \\
\text { TAPANULI TENGAH }\end{array}$ & \begin{tabular}{|l} 
1. Kebijakan pemerintah dalam \\
mendukung pengelolaan aset \\
2. Adanya hubungan baik antar \\
SKPD pengelola aset \\
3. Manajemen dan struktur \\
organisasi yang jelas \\
4. Sumberdaya aparatur \\
pengelola aset secara \\
kuntitas cukup memadai \\
5. Pagu anggaran pengelola aset \\
dalam mendukung \\
peningkatan kinerjapegawai \\
pengelola aset daerah \\
Adanya komitmen \\
yang kuat dari seluruh \\
pengelola aset dalam \\
mewujudkan tujuan \\
organisasi
\end{tabular} & 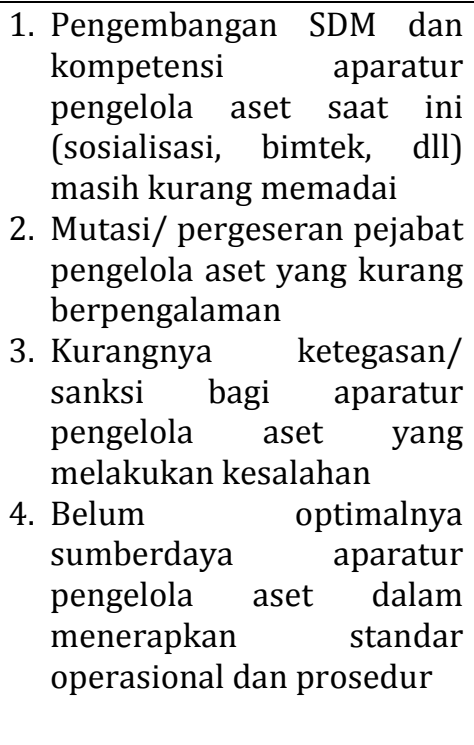 \\
\hline Peluang (0) & Strategi S-O & Strategi W-0 \\
\hline $\begin{array}{l}\text { 1.Peraturan tentang tata } \\
\text { kelola aset daerah, untuk } \\
\text { mempermudah tata kelola } \\
\text { sesuai dengan aturan } \\
\text { 2.Dana insentif daerah (DID) } \\
\text { bagi pemerintah daerah } \\
\text { yang berkinerja baik/ opini } \\
\text { WTP } \\
\text { 3. Komitmen pemerintah } \\
\text { dalam meningkatkan } \\
\text { kualitas aparatur, seperti } \\
\text { pengiriman pns untuk tugas } \\
\text { belajar } \\
\text { 4. Fungsi pengawasan } \\
\text { terjadwal dari dprd dan } \\
\text { pengawasan LSM Tapanuli } \\
\text { Tengah saat dibutuhkan }\end{array}$ & $\begin{array}{l}\text { Sinkronisasi Peraturan } \\
\text { Pemerintah pusat, provinsi } \\
\text { dengan kebijakan Pemerintah } \\
\text { Kabupaten Tapanuli Tengah } \\
\text { dalam mendukung Pengelolaan } \\
\text { Aset }(S 1,01,03)\end{array}$ & $\begin{array}{l}\text { Meningkatkan dukungan } \\
\text { kebijakan pemerintah, baik } \\
\text { pusat dan daerah dalam } \\
\text { pengembangan SDM dan } \\
\text { peningkatan kompetensi } \\
\text { pengelola aset daerah melalui } \\
\text { pelatihan penatausahaan aset } \\
\text { untuk mempermudah tata } \\
\text { kelola sesuai dengan aturan. } \\
(W 1,01,03)\end{array}$ \\
\hline Ancaman (T) & Strategi S-T & Strategi W-T \\
\hline $\begin{array}{l}\text { 1.Pengadaan sistem dan } \\
\text { teknologi yang terbatas dan } \\
\text { tidak sesuai antara pusat, } \\
\text { provinsi dan } \\
\text { kabupaten/kota } \\
\text { 2. Kondisi alam dan lokasi } \\
\text { aset yang cukup jauh dari } \\
\text { jangkauan sehingga } \\
\text { pendataan sulit dilakukan } \\
\text { 3. Pengakuan masyarakat atas } \\
\text { aset pemda yang } \\
\text { disebabkan lemahnya } \\
\text { penatausahaan }\end{array}$ & $\begin{array}{l}\text { Peningkatan kebijakan } \\
\text { pemerintah dalam } \\
\text { pengembangan dan penerapan } \\
\text { sistem dan teknologi untuk } \\
\text { mendukung pengawasan dan } \\
\text { pengendalian dalam } \\
\text { pengelolaan aset di Kabupaten } \\
\text { Tapanuli Tengah.(S1,T1,T3) }\end{array}$ & $\begin{array}{l}\text { Peningkatan hubungan baik } \\
\text { antar SKPD pengelola aset, } \\
\text { terutama dalam penerapan } \\
\text { sistem dan teknologi yang } \\
\text { terintegrasi dalam } \\
\text { pengelolaan aset di Kabupaten } \\
\text { Tapanuli Tengah.(W1, T1,T3) }\end{array}$ \\
\hline
\end{tabular}

Gambar 2. Matrik SWOT 


\section{Prioritas Strategi}

Hasil pengolahan data matriks SWOT tersebut, diperoleh 4 grand strategi. Strategi tersebut disebarkan ke beberapa orang expert , untuk memperoleh strategi prioritas. Pihak-pihak yang dianggap sebagai ahli/pakar dalam hal ini terdiri dari Sekretaris daerah, Kepala dinas PPKAD, Sekretaris dinas PPKAD, Kepala bidang aset dan 3 orang Kepala seksi pada bidang aset. Dari ketujuh para pakar/ahli tersebut diminta untuk membandingkan 4 grand strategi tersebut untuk diperingkatkan.
Hasil pembobotan strategi dengan menggunakan metode pairwise comparison (matrik perbandingan berpasangan) terhadap strategi peningkatan kinerja aparatur pengelola aset di Kabupaten Tapanuli Tengah menunjukkan hasil bahwa strategi meningkatkan dukungan kebijakan pemerintah, baik pusat dan daerah dalam pengembangan SDM dan peningkatan kompetensi pengelola aset daerah melalui pelatihan penatausahaan aset untuk mempermudah tata kelola sesuai dengan aturan, merupakan strategi dengan prioritas pertama dengan bobot 0.474 .

Tabel 3. Hasil Pembobotan Strategi Peningkatan Kinerja Aparatur Pengelola Aset di Kabupaten Tapanuli Tengah

\begin{tabular}{clcc}
\hline No. & \multicolumn{1}{c}{ STRATEGI } & Bobot & Prioritas \\
\hline 1 & $\begin{array}{l}\text { Meningkatkan dukungan kebijakan pemerintah, baik pusat dan daerah dalam } \\
\text { pengembangan SDM dan peningkatan kompetensi pengelola aset daerah melalui } \\
\text { pelatihan penatausahaan aset untuk mempermudah tata kelola sesuai dengan aturan }\end{array}$ & 0.4743 & 1 \\
& $\begin{array}{l}\text { Peningkatan kebijakan pemerintah dalam pengembangan dan penerapan sistem dan } \\
\text { teknologi untuk mendukung pengawasan dan pengendalian dalam pengelolaan aset } \\
\text { di Kabupaten Tapanuli Tengah. }\end{array}$ & 0.2232 & 2 \\
& $\begin{array}{l}\text { Peningkatan hubungan baik antar SKPD pengelola aset, terutama dalam penerapan } \\
\text { sistem dan teknologi yang terintegrasi dalam pengelolaan aset di Kabupaten } \\
\text { Tapanuli Tengah. }\end{array}$ & 0.1743 & 3 \\
& $\begin{array}{l}\text { Sinkronisasi Peraturan Pemerintah pusat, provinsi dengan kebijakan Pemerintah } \\
\text { Kabupaten Tapanuli Tengah dalam mendukung Pengelolaan Aset }\end{array}$ & 0.1282 \\
\end{tabular}

\section{KESIMPULAN}

1. Sistem pengawasan dan pengendalian pengelolaan aset belum sepenuhnya dapat diandalkan karena beberapa SKPD belum memiliki database yang memadai.

2. Terdapat beberapa penyebab pengelolaan Aset yang belum maksimal di Kabupaten Tapanuli tengah; a) Pengembangan SDM dan kompetensi aparatur pengelola aset saat ini (sosialisasi, bimtek, dll) masih kurang memadai, b) Mutasi/ pergeseran pejabat pengelola aset yang kurang berpengalaman, c) Kurangnya ketegasan/ sangsi bagi aparatur pengelola aset yang melakukan kesalahan, dan d) Belum optimalnya sumberdaya aparatur pengelola aset dalam menerapkan standar operasional dan prosedur

3. Strategi yang menjadi prioritas utama dalam meningkatkan kinerja pengelola aset antara lain, Meningkatkan dukungan kebijakan pemerintah, baik pusat dan daerah dalam pengembangan SDM dan peningkatan kompetensi pengelola aset daerah melalui pelatihan penatausahaan aset untuk mempermudah tata kelola sesuai dengan aturan.

\section{SARAN}

Disarankan kepada pemerintah daerah Tapanuli Tengah fokus pada strategi meningkatakan SDM serta kompetensi pengelola aset daerah melalui pelatihan 
penatausahaan aset dengan instansi pemerintah maupun lembaga yang diakui oleh pemerintah, antara lain: 1) diklat penatausahaan aset daerah, 2) diklat pengadaan barang dan jasa, 3) diklat pengawasan keuangan dan aset, 4) diklat penyusunan laporan barang/aset, 5) diklat penyusunan anggaran berbasis kinerja, 6) diklat pengelolaan barang milik daerah, 7) diklat aplikasi keuangan dan komputerisasi, 8) diklat penilaian aset.

\section{DAFTAR PUSTAKA}

Afandi Muhamad Nur, Khairani. 2013. Analisis Manajemen Aset Tetap di Dinas Pendapatan, Pengelolaan Keuangan dan Aset Daerah Kota Tanjung Balai. Jurnal Ilmu Administrasi, Vol $\mathrm{X}$, No. 3 Desember 2013, hal. $393-414$

Laporan Hasil Pemeriksaan BPK RI Atas

Laporan Keuangan Pemerintah Kabupaten Tapanuli Tengah Tahun 2013

Peraturan Menteri PAN dan RB Nomor 29

Tahun 2010. tentang Pedoman Penyusunan Penetapan Kinerja dan Pelaporan Akuntabilitas Kinerja Instansi Pemerintah

Tarr, James D. 1996. Performance Measurements for a Continuous Improvement Strategy, Hospital Materiel Management Quarterly, 18, 2; ProQuest, pg. 77, California, USA

Undang - Undang Republik Indonesia

Nomor 17 Tahun 2003 tentang

Keuangan Negara 